\title{
Neoplastic Plasma Cells 30 Percent or More of Bone Marrow Nucleated Cells
}

National Cancer Institute

\section{Source}

National Cancer Institute. Neoplastic Plasma Cells 30 Percent or More of Bone Marrow

Nucleated Cells. NCI Thesaurus. Code C157367.

A semi-quantitative microscopic finding indicating that at least 30 percent of the nucleated cells in a bone marrow sample are neoplastic plasma cells. 